\title{
DIET FOR CHILDHOOD SICKLE CELL ANEMIA (SCA) - AYURVEDA VIEW
}

\section{KURKUTIYA K ${ }^{1}$ AND RASKAR SC ${ }^{2 *}$}

1: PG Scholar; Dept of Kaumarabhritya, Parul Institute of Ayurved, Parul University, Vadodara; Gujarat

2: Associate Professor; Dept of Kaumarabhritya, Parul Institute of Ayurved, Parul University, Vadodara; Gujarat

*Corresponding Author: Dr. Swapnil C Raskar: E Mail: neonatecare99@gmail.com Received $12^{\text {th }}$ Dec. 2021; Revised $14^{\text {th }}$ Jan. 2022; Accepted $7^{\text {th }}$ Feb. 2022; Available online $5^{\text {th }}$ March 2022 https://doi.org/10.31032/IJBPAS/2022/11.3.1080

\begin{abstract}
Background: - Sickle cell anemia (SCA) is a term for a group of genetic diseases characterized by the production of hemoglobin $(\mathrm{Hb})$ " $\mathrm{S}$ " and it is chronic in nature with painful crisis, lead to aliered quality of life in children. Presently, there is no definite treatment other than a successful bone marrow transplant for SCA. Its symptoms and the nature of the disease can be compared with Pandu in Ayurveda literature. Considering the pathogenesis of Pandu and symptoms of Sickle cell anemia in present article the diet measures and regimen for children with sickle cell anemia has been discussed. Material and Methods: Different literature on diet on sickle cell anemia and Ayurveda literature were reviewed in this article. Data Source and Review Methods: Data on the SCA and Pandu has been reviewed from all possible Ayurveda Texts, also the different research articles on SCA and Pandu from all scientific indexed journal research papers, Pubchem and other authenticated data bases has been reviewed, analysed, discussed and concluded. Discussion and Conclusion: SCA cases can be considered as Rasa-Rakta Kshaya and the diet and herbs which improve the Dhatu Poshana (Cellular nutrition) Rasa-Rakta Dhatu are useful in the management of SCA to improve the nourishment and quality of life of these children.
\end{abstract}

Keywrods: Ayurveda diet, Pandu, Sickle Cell Anemia (SCA), Rasa-Rakta Kshaya 
INTRODUCTION: Sickle cell anemia is a heterogenous autosomal recessive disorder. Anemia, fatigue, loss of appetite, recurrent episodes of arthralgia especially small joints of phalanges is the classical features of Sickle Cell Anemia. As it is a genetic disorder, there is no direct medical management for cure of disease, nevertheless there is palliative care of disease has been evolved in last decade. Considering the widerange of symptoms due to difference in gene expression proportion, researchers are in search of the newer treatment protocol. Complimentary and traditional systems of medicines having enriched heritage of herbs and other medicines which can be useful for treatment of diseases like SCA. India having verity of crops, and herbal flora, which is in used in different folk lore practices for different diseases. Ayurveda (Traditional system of Indian Medicines) defines the properties of food and its uses in different diseases in detail. In this article an attempt has been made to classify the diet on the basis of Ayurveda fundamentals which can be useful in the diet protocol of Sickle Cell Anemia in children.

Sickle Cell Anemia and Ayurveda: There is no direct hand in hand corelation of SCA with direct Ayurveda diseases. Sets of symptoms of SCA can be corelated with some Ayurveda disease entity like Rasa Kshaya, Rakta Kshata and Pandu Roga.

\section{MATERIAL AND METHODS:}

Different literature on diet on sickle cell anemia and Ayurveda literature were reviewed in this article.

\section{DATA SOURCE AND REVIEW} METHODS: Data on the SCA and Pandu has been reviewed from all possible Ayurveda Texts, also the different research articles on SCA and Pandu from all scientific indexed journal research papers, Pubchem and other authenticated data bases has been reviewed, analysed, discussed and concluded.

Table No.1: Correlation of Symptoms of Sickle Cell Anemia with Pandu Roga

\begin{tabular}{|c|c|}
\hline Symptoms of SCA & Nearer terminology of Ayurveda \\
\hline Pallor & Panduta \\
\hline Fatigue & Daurbalya \\
\hline Leg cramps & Pindikodweshtana \\
\hline Growth retardation & Karshya \\
\hline Recurrent Illness & Sada aatura \\
\hline
\end{tabular}

DISCUSSION: There are other many herbs and diet substances having therapeutic properties and can be used to treat different haematological disorders including SCA in children.

Grains also contain Folate that for synthesis of new red blood cells ${ }^{1}$. Grains are also rich 
in vitamin $\mathrm{B}$ groups $^{23}$, magnesium important for healthy bones ${ }^{4}$ selenium- important for healthy immune system ${ }^{5}$ Sources: peanuts, lettuce, spinach strawberries, papaya, asparagus, Corn, orange juice, enriched or fortified products ${ }^{6}$ Spinach, carrots, broccoli, tomato, green beans full of vitamins and minerals such as fibre, folate, potassium, etc. It will help protect against infections, heal wounds, and keep eyes and skin healthy. ${ }^{7}$ Apples, oranges, bananas, grapes, melon, berries, kiwi, plums, peach, etc. These fruits can provide similar vitamins, minerals and fibre as vegetables ${ }^{8}$. Liquid vegetable oils such as olive, canola, corn oil, and nuts are rich inomega-3 fatty acids vitamin $\mathrm{E}$, which works as an antioxidant to help to prevent disease. ${ }^{9}$ Chicken, pork, fish and beef, nuts, seeds, peas and beans are great sources of protein, zinc, iron and omega-3 fatty acids. ${ }^{10}$ Low fat milk, yogurt and cheese contain Calcium and Vitamin D - for strong, healthy bones ${ }^{11}$ Lean chicken, pork, fish and beef, nuts, seeds, peas and beans contain Omega 3 fatty acids -in certain fish, nuts and seeds-help to reduce inflammation and decrease risk of chronic diseases $^{12}$

Arginine - Arginine metabolism is impaired in SCD and contributes to endothelial dysfunction, vaso-occlusive crises, and pulmonary hypertension.
Arginine deficiency develops over time so that by adulthood it achieves a low steady state. Due to the interaction between arginine availability and nitric oxide levels, lack of adequate amounts of arginine leads to disruption of vascular homeostasis and oxidative stress. Therefore, in SCD arginine becomes an essential amino acid. ${ }^{13}$ arginine is a substrate for the synthesis of nitric oxide, which is a potent vasodilator. Low nitric oxide availability is considered a central feature of endothelial dysfunction and ultimate vasoocclusive crises in sickle cell disease. ${ }^{14}$ Nuts and seeds are significant sources of arginine. ${ }^{15}$ Pumpkin seeds have one of the highest concentrations of the amino acid, with a cup of dried pumpkin or squash seeds providing 6.905 grams (g) of arginine. ${ }^{16}$ Sesame seeds are also a good source of arginine, providing $4.875 \mathrm{~g}$ per cup. ${ }^{17}$ dried walnuts contain $4.522 \mathrm{~g}$ per cup ${ }^{18}$ almonds contain 3.525 g per cup $^{19}$ pine nuts contain $3.258 \mathrm{~g}$ per $\operatorname{cup}^{20}$ Foods with high nitrate and nitrite content include beets, spinach, radishes, celery, and mustard greens. Providing food sources of antioxidant Vitamins E, C and A (beta-carotene) can also boost the glutathione antioxidant defense system and work together with arginine-derived nitric oxide to combat oxidative stress. $^{21}$ 
Glutamine- becomes conditionally essential in sickle cell disease due to its increased requirement. Deficiency for glutamine availability may result in metabolic stress, increased resting energy expenditure (REE), muscle wasting and decreased immune function. Glutamine is also a precursor of NAD, and recent research indicates that glutamine may make sickle RBCs less adhesive. Evidence suggests that a pharmaceutical grade of Lglutamine is beneficial for decreasing the incidents of SCD-related vaso-occlusive (VOC) pain events without significant safety concerns. ${ }^{22}$ Seafood, including fish, sardines, lobsters, prawns, mussels, shrimps, and crabs, is a great source of glutamine. Salt-water fish has higher glutamine content in comparison with freshwater fish. ${ }^{23}$ Meat is considered as one of the best sources of glutamine and protein. Consumption of chicken, lamb, pork, and beef can effectively improve glutamine levels in the body. ${ }^{24}$ Eggs are incredibly nutritious and are beneficial for overall health. Not only do eggs provide a high quantity of glutamine, but they are also rich in Vitamin K, B, B12, A and D, omega-3 fatty acids, antioxidants, iron, iodine, phosphorous, biotin, thiamine, selenium, and high-quality protein. ${ }^{25}$ Dairy products such as milk, cheese and yogurt are glutamine-rich foods. ${ }^{26}$ Milk contains high amounts of calcium, protein, potassium, and vitamin $\mathrm{D}$ that promote bone and tissue repair. ${ }^{27}$ The leafy green is another 'super food' and classified as one of the world's healthiest food, loaded with nutrients and has small calories, so good to eat. It is rich in iron, contains protein, minerals and vitamins (A, B1, B2, B6, C, E, K) and folic acid. It also contains calcium, potassium, manganese, magnesium, zinc etc...It is known to add vitality, improve the quality of the blood and repair energy. ${ }^{28}$

Thiocyanate - SCA is a congenital deficiency anemia, ameliorable by prophylactic diets of foods with high SCNcontents. Thus, "thiocyanate deficiency anemia" is nutritionally a more correct clinical status for those born with the homozygous sickle hemoglobin genome. Just as any iron undernourished person can suffer from iron deficiency anemia, sickle hemoglobin homozygotes suffer from "thiocyanate deficiency anemia. ${ }^{29}$

Thiocyanate is being used as anti-sickling drugs. ${ }^{30}$ Dietary thiocyanate derived from, millet, sorghum, plantain, banana, almonds, cabbage, carrots, cauliflower, lentils, lima beans, beans, peanuts, beetroots and plums. ${ }^{31}$ Folate- Sources of folate include all green leafy vegetables such as beetroots, broccoli; sweet corn, beans and legumes, fortified cereals, beef liver, orange and 
pineapple juices. $^{32}$ Food sources for vitamin B6 include meat, oily fish, vegetables, whole grains, beans, groundnuts, potatoes, banana, plantain, and mushrooms. Since red blood cells are rapidly destroyed, iron is stored in the liver, hence all animal sources of protein which are very rich sources of iron, as well as vitamin $\mathrm{B} 12$ and zinc should be eaten cautiously to prevent iron overdose. ${ }^{33}$ Citrulline-Another important nutrient is citrulline, which is a quick absorbing amino acid that promotes blood vessels relaxation, improving oxygen and blood circulation in all parts of the body. Rich food source of citrulline is watermelon, including the rind (the white portion before the green back of the watermelon) and seeds. Since it might be difficult chewing the seeds, watermelon fruit juice could be prepared by blending the flesh with the rind and seeds. ${ }^{34}$ Other sources include milk, legumes and cucumber. Current research has also found that drinking unsweetened pure cocoa powder every day helps improve on complications associated with sickle cell disease because cocoa is enriched with most of the nutrients needed by sickle cell individuals. $^{35}$

Table No.2: Diet for Sickle Cell on the basis of Evidence based medicines and research articles

\begin{tabular}{|c|c|c|}
\hline Nutrients & $\begin{array}{l}\text { Role in SCA } \\
\end{array}$ & Diet Sources \\
\hline Arginine & $\begin{array}{c}\text { as substrate for the synthesis of nitric oxide, } \\
\text { which is a potent vasodilator }\end{array}$ & $\begin{array}{l}\text { Pumpkin seeds, Sesame seeds, dried } \\
\text { walnuts, Almonds, pine nuts, Beets, } \\
\text { spinach, radishes, celery, and mustard } \\
\text { greens }\end{array}$ \\
\hline Citrulline & $\begin{array}{c}\text { blood vessels relaxant, improving oxygen } \\
\text { and blood circulation }\end{array}$ & $\begin{array}{c}\text { Watermelon, milk, legumes and } \\
\text { cucumber, unsweetened pure cocoa } \\
\text { powder, }\end{array}$ \\
\hline Folate & $\begin{array}{l}\text { Hemopoietic action on Bone marrow, } \\
\text { Imparts immunity, eye and skin health }\end{array}$ & $\begin{array}{l}\text { Whole grain, rice, pastas, cereals and } \\
\text { crackers, beetroots, broccoli; sweet } \\
\text { corn, beans and legumes, fortified } \\
\text { cereals, orange, pineapple juices }\end{array}$ \\
\hline Glutamine & $\begin{array}{l}\text { make sickle RBCs less adhesive, decreasing } \\
\text { the incidents ofVaso-occlusive crises (VOC) }\end{array}$ & $\begin{array}{c}\text { Seafoodfish sardines, lobsters, prawns, } \\
\text { mussels, shrimps,crabs, milk, cheese } \\
\text { and yogurt }\end{array}$ \\
\hline Magnesium & $\begin{array}{l}\text { reduced the number of dense erythrocytes, } \\
\text { improved the erythrocyte membrane } \\
\text { transport abnormalities, protect against } \\
\text { losses of water and potassium }\end{array}$ & Nuts, legumes, seeds \\
\hline Omega-3 Fatty Acids & $\begin{array}{c}\text { Anti-sickling, Anti-haemolytic and } \\
\text { antioxidant }\end{array}$ & $\begin{array}{c}\text { salmon, mackerel, tuna, herring, } \\
\text { sardines, flaxseed, chia seeds, walnuts, } \\
\text { flaxseed oil, soybean oil, canola oil, eggs, } \\
\text { yogurt, milk, soy beverages }\end{array}$ \\
\hline Protein & $\begin{array}{c}\text { Improved weight gain, reduced } \\
\text { inflammatory proteins CRP and IL-6, } \\
\text { increase the availability of Amino acids }\end{array}$ & \\
\hline Thiocyanate & Anti-sickling drugs, oxygen carrier & $\begin{array}{l}\text { yam, cassava, millet, sorghum, plantain, } \\
\text { banana, almonds, broccoli cabbage, } \\
\text { carrots, cauliflower, lentils, lima beans, } \\
\text { beans, peanuts, beetroots, lums }\end{array}$ \\
\hline Zinc & $\begin{array}{c}\text { Reduce RBC's dehydration, Antibacterial } \\
\text { protection, Immunity booster, Improves } \\
\text { growth, Reduced the number of dense } \\
\text { erythrocytes, }\end{array}$ & Meat, legumes, eggs, diary \\
\hline
\end{tabular}


Table No.3: Composition of the sickle diet and Regular $\operatorname{diet}^{36}$

\begin{tabular}{|c|c|c|}
\hline Contents & Sickle Cell Diet & Regular Diet \\
\hline Protein (\% Weight) & 26.4 & 18.6 \\
\hline Fat (\% Weight) & 11.1 & 6.2 \\
\hline Carbohydrate (\% Weight) & 62.5 & 44.2 \\
\hline Protein (\% Calories) & 27.5 & 24 \\
\hline Fat (\% Calories) & 26 & 18 \\
\hline Carbohydrate (\% Calories) & 46.5 & 58 \\
\hline Arginine (\%) & 2.52 & 1 \\
\hline Aspartic Acid (\%) & 2.53 & 1.4 \\
\hline Glutamic Acid (\%) & 5.16 & 3.4 \\
\hline Magnesium (\%) & 0.48 & 0.2 \\
\hline Sulfur (\%) & 0.29 & $\mathbf{0}$ \\
\hline Zinc (mg/kg) & 225 & 70 \\
\hline Vitamin A (IU/g) & 33 & 15 \\
\hline Vitamin D3(IU/g) & 3.3 & 1.5 \\
\hline Vitamin E(IU/kg) & 200 & 110 \\
\hline Folic acid (mg/kg) & 8 & 4 \\
\hline Vitamin B12(mcg/kg) & 60 & 80 \\
\hline Cholin Chloride (mg/kg) & 2200 & 1200 \\
\hline
\end{tabular}

Omega-3 Fatty Acids EPA/DHA-DHA, EPA, and their respective metabolites are known to exert a myriad of biochemical and biologic effects, directly and indirectly, including through competitive inhibition of actions of AA and its metabolites. However, the synergistic effects of decreased inflammation, blood cell aggregation, adhesion, and oxidative stress and of increased vasodilatation and blood flow may have played a critical role in the amelioration of vaso-occlusive and haemolytic crises in the patients. ${ }^{37}$ Proposed mechanism of undernutrition include protein hypermetabolism, decreased dietary intake possibly from interleukin-6-related appetite suppression, increased cardiac energy demand/expenditure, and increased red cell turnover. $^{38}$

Multimodal Therapy-The combination of thiocyanate and omega-3 fatty acids includes agents with antisickling, antiadhesion, and cell membranestabilizing effects. Therefore, this combination has the potential to inhibit three mechanisms of sickle cell diseaseerythrocyte sickling, blood vessel occlusion, and haemolysis. ${ }^{39}$ Omega-3 fatty acids EPA/DHA have antisickling, antihemolytic and antioxidant properties. The results obtained are in addition to those of the authors who showed that Omega-3 fatty acids EPA/DHA was effective at reducing the frequency and severity of haemolysis, vaso-occlusive episodes, severe anemia, and blood transfusion. ${ }^{40}$

Omega-3s are found naturally in some foods and are added to some fortified foods, including the following: Fish and other seafood (especially cold-water fatty fish, such as salmon, mackerel, tuna, herring, and sardines) Nuts and seeds (such as flaxseed, chia seeds, and walnuts) Plant 
oils (such as flaxseed oil, soybean oil, and canola oil) Fortified foods (such as certain brands of eggs, yogurt, juices, milk, soy beverages, and infant formulas ${ }^{41}$

Protein-A high protein diet improved weight gain and reduced inflammatory proteins CRP and IL-6 in the Berkeley mouse model of sickle cell disease. We believe that the high protein diet is increasing the availability of amino acids, which have become limited in sickle cell disease, because of an increased demand on protein synthesis for red cell replacement. This increased metabolic demand is not satisfied by a diet that is adequate for healthy individuals with normal hemoglobin. ${ }^{42}$

\section{ROLE OF MICRONUTRIENTS:}

Zinc- Zinc sulphate has been found quite effective in reducing RBC's dehydration. It is found to reduce sickle cell crises, pain and other life-threatening complications. Zinc supplementation not only improved growth and weight of SCD children, but also gave a boost to their immunity by offering antibacterial protection, thereby making its supplementation essential. ${ }^{43}$

Magnesium- It was found to protect against losses of water and potassium in SCD patients. Magnesium deficiency was found to increase episodes of sickling by causing cell dehydration in sickled erythrocytes. In SCD patients it has been found that magnesium supplementation reduced the number of dense erythrocytes and also improved the erythrocyte membrane transport abnormalities of patients with SCD

Copper- Copper deficiency is linked to anemia, being a key ingredient for functioning of metalloenzymes (e.g. ceruloplasmin), and plays an important role in iron metabolism. Ceruloplasmin helps to mobilize stored iron in the liver and make it more available for synthesis of $\mathrm{Hb}$. Importantly, in copper deficiency anemia the synthesis rate of $\mathrm{Hb}$ is reduced, despite increased iron levels in the liver.

Chromium- Chromium is another element which helps in the management of SCD. It acts not only as a cofactor, at receptor sites of the insulin sensitive cell membrane but it also plays a role in carbohydrate metabolism which is the body's much required energy source in SCD.

Manganese (Mn)- Manganese which helps in glycoprotein synthesis and bone formation is also important for management of SCD. It also acts as cofactor of pyruvate carboxylase which participates in the respiratory chain reaction required for the much needed energy production, for SCD patients.

Blood deficiency of several vitamins such as $\mathrm{A}, \mathrm{B} 6, \mathrm{C}, \mathrm{D}, \& \mathrm{E}$ and minerals like zinc, $\mathrm{Mg}$ is observed in patients with SCD by 
many researchers, which are the most factors contributing towards their poor growth and weight. These deficiencies cause a significant reduction in the concentrations of blood antioxidant levels in SCD patients resulting in VOC related ACS. The decrease in concentration of antioxidant vitamins $\mathrm{A}, \mathrm{C}$, and $\mathrm{E}$ is responsible for increased hemolysis and susceptibility to bacterial infections in SCD. Decreases in arterial blood pressure reduction in the percentage of sickle cells, was observed with a collective supplementation of vitamins like A, C, and $\mathrm{E}$, besides an increase in concentration of hemoglobin and packed cell volume.

\section{Role of vitamins}

Vitamin E- In vitro studies also established that vitamin $\mathrm{E}$ possesses anti-sickling property and therapeutic benefits in sickle cell anemia cases. ${ }^{44}$ Vitamin B6- Vitamin B6 is known for its crucial roles in different metabolic pathways in the body like ingestionof food, derivatization to the fueling molecule glucose and assisting in the metabolism of lipids and proteins. The biological potent form of vitamin B6, namely pyridoxal 5' phosphate (PLP) functions as a cofactor for many of the enzymes involved in amino acid metabolism as well as the formation of neurotransmitters like serotonin, dopamine, epinephrine, and gamma amino-butyric acid. Vitamin D- SCD patients are prone to bone fractures and often the vitamin D status is found to be very low, putting them at great risk. Routine supplementation with vitamin D helps maintain the vitamin levels in such patients

\section{AYURVEDA VIEW:}

After analysing the diet of SCA children with regular diet; it has been observed that there is increased need of the nutrients and micronutrients in children with SCA.

As explained earlier there is Rasa-Rakta Kshaya in children with SCA and hence there are increases nutritional demands of these children than normal children. Ayurveda herbals and dietary food stuff can be useful to fulfil this requirement.

Table No.4: Ayurveda food stuff and herbs for haematological disorders

\begin{tabular}{|c|c|c|c|}
\hline Dravya & Qualities & Used in & Modern Corelation \\
\hline Amalaki & $\begin{array}{c}\text { Rejuvenating, Improves } \\
\text { blood quality }\end{array}$ & $\begin{array}{c}\text { Anemia, as } \\
\text { immunomodulator }\end{array}$ & $\begin{array}{c}\text { Rich source of Vit C and } \\
\text { Antioxidants }\end{array}$ \\
\hline Draksha & $\begin{array}{c}\text { Laxative and Nutritious } \\
\text { food for children }\end{array}$ & $\begin{array}{c}\text { Anemia, Fatigue, } \\
\text { Malnutrition }\end{array}$ & $\begin{array}{c}\text { Source of Vit C and } \\
\text { Copper }\end{array}$ \\
\hline Dhanyaka & $\begin{array}{c}\text { Appetizer and } \\
\text { carminatives }\end{array}$ & $\begin{array}{l}\text { Indigestion, flatulence, } \\
\text { Urinary tract infections }\end{array}$ & $\begin{array}{c}\text { Antioxidant, Antidiabetic, } \\
\text { Hepatoprotective, } \\
\text { Antibacterial, and } \\
\text { Antifungal activities }\end{array}$ \\
\hline Shunthi & $\begin{array}{c}\text { Appetizer and } \\
\text { carminatives }\end{array}$ & Indigestion, flatulence & Antioxidant, Antidiabetic, \\
\hline Pippali & $\begin{array}{c}\text { Appetizer and } \\
\text { carminatives }\end{array}$ & $\begin{array}{c}\text { Indigestion, flatulence, } \\
\text { blood disorders }\end{array}$ & $\begin{array}{l}\text { All types of Anemia and } \\
\text { haematological disorders }\end{array}$ \\
\hline Chitraka & $\begin{array}{c}\text { Appetizer and } \\
\text { carminatives }\end{array}$ & $\begin{array}{c}\text { Indigestion, flatulence, } \\
\text { haemorrhoids }\end{array}$ & Antipyretic, analgesic \\
\hline
\end{tabular}


In Nut Shell diet of Children with SCA should be -

1. Easy to digest - Ayurveda gives utmost important to digestion capacity of an individual (Agni)

2. Should suffices RDA of all food micro and macro nutrients
3. Plenty of liquid

4. Rich in Vitamin C, E and D

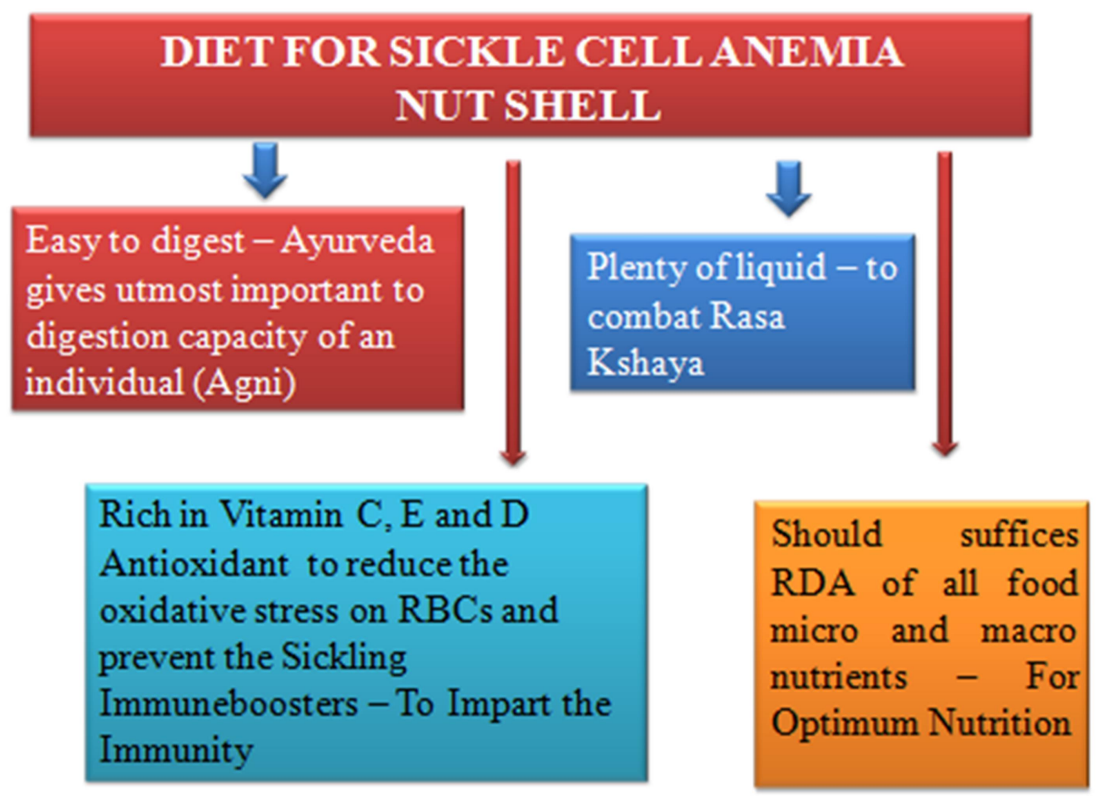

Figure 1: In Nut Shell diet of Children with SCA

Few food stuffs are explained in succeeding Paragraphs.

Dadima like fruit helped deal with all important aspects of Pandu i.e. Pallor, Anorexia, pain (limb), fever, periorbital edema, and fatigue. Drug-like Chitraka, Dhanyaka, Shunthi pippali which are traditionally used in Indian cooking improves the process of digestion, Pachana (like drug Pippali) detoxifies the body by removing Ama toxins it also exerts the antioxidant effect and arrest the free oxygen species and helps to improve the oxidative stress on tissues in children with SCA. It improves digestion and reduces the accumulation of harmful cholesterol in the body, thereby improving metabolism and helping the body lose weight faster, which helps to establish proper nutrition for all Dhatu and is beneficial for Dhatuposhana. Dadim, Dhanyaka, and Shunti have antioxidant activity, help reduce sickle cell oxidative stress, and help prevent sickle cell anemia 
and SCA screaming. Dipana and Pachana preparations can improve the digestive process and eliminate damaged Dosha or Aama in the body. It also showed significant results of orbital edema, loss of appetite in Pitta and Vata Dushti, the elevation of Vata and Pitta Dosha, and the drug Rakta Prasadana Karma which can relieve edema. Hemopoetic action of the Dadima and Amalaki stimulates the hemopoesis and production of healthy RBCs in the children with sickle cell anemia. Coriandrum sativum L. has been recommended for relief of insomnia in Iranian traditional medicine. In sickle cell anemia there is painful condition which lead to disturbed sleep and it is relieved by the Dhanyaka. ${ }^{45}$

Glimpse of Classical Indian Staple Diet for SCA

\begin{tabular}{|c|c|c|c|}
\hline Diet time & Diet items & Particulars & Role in SCA \\
\hline Break Fast & $\begin{array}{l}\text { Sprouts - } \\
\text { Fruits - }\end{array}$ & $\begin{array}{c}\text { Green gram, Black gram } \\
\text { Pomegranate, Apple }\end{array}$ & $\begin{array}{l}\text { Protenicous healthy diet to } \\
\text { demand the daily calory } \\
\text { need. Fruits are } \\
\text { antioxidant which reduces } \\
\text { the oxidative stress }\end{array}$ \\
\hline Lunch & $\begin{array}{c}\text { Millets } \\
\text { Lentils } \\
\text { Leafy Vegetable } \\
\text { Oil }\end{array}$ & $\begin{array}{l}\text { Ragi, Jowar, bajra, Maize } \\
\text { Corn drop oil, olive oil, } \\
\text { canola, nuts }\end{array}$ & $\begin{array}{c}\text { Reach source of natural } \\
\text { iron and helps healthy } \\
\text { hematopoesis }\end{array}$ \\
\hline Evening Snacks & Beverages & $\begin{array}{c}\text { Low fat milk, yogurt and } \\
\text { cheese }\end{array}$ & $\begin{array}{c}\text { Maintain nutrition and } \\
\text { digestion }\end{array}$ \\
\hline Dinner & $\begin{array}{c}\text { More Liquid and easily } \\
\text { digestible food stuff reach } \\
\text { in protiens }\end{array}$ & $\begin{array}{l}\text { Yusha - Gruels made of } \\
\text { Pulses and Cow Ghee }\end{array}$ & $\begin{array}{l}\text { Improves hydration and } \\
\text { nutrition gives strength }\end{array}$ \\
\hline
\end{tabular}

CONCLUSION: There is definite role of diet to combat the SCA. Ayurveda guidelines and diet is useful to treat the children with SCA along with Modern conventional treatment.

\section{REFERENCES:}

1 Boston Medical Center Department of Food and Nutrition Services, https://www.bmc.org/sites/default/files/Abo ut_Us/Features/Sickle_Cell_Disease_Treat ment_at_BMC/field_Attachments/SickleCe llDisease-EatingHealthy.pdf, accessed on $21^{\text {st }}$ august $2021 @ 10: 40$
${ }^{2}$ Salome phelamie, A balanced diet for people with sickle cell disease: 6 food groups and how they help your body, https://www.timesnownews.com/health/arti cle/a-balanced-diet-for-people-with-sicklecell-disease-6-food-groups-and-how-theyhelp-your-body/652199. accessed on $21 \mathrm{st}$ august2021@10:20

${ }^{3}$ Boston Medical Center Department of Food and Nutrition Services, https://www.bmc.org/sites/default/files/Abo ut_Us/Features/Sickle_Cell_Disease_Treat ment_at_BMC/field_Attachments/SickleCe 
1lDisease-EatingHealthy.pdf, accessed on $21^{\text {st }}$ august $2021 @ 10: 38$

${ }^{4}$ Boston Medical Center Department of Food and Nutrition Services, https://www.bmc.org/sites/default/files/Abo ut_Us/Features/Sickle_Cell_Disease_Treat ment_at_BMC/field_Attachments/SickleCe 11Disease-EatingHealthy.pdf, accessed on $21^{\text {st }}$ august $2021 @ 10: 39$

5 Boston Medical Center Department of Food and Nutrition Services, https://www.bmc.org/sites/default/files/Abo ut_Us/Features/Sickle_Cell_Disease_Treat ment_at_BMC/field_Attachments/SickleCe llDisease-EatingHealthy.pdf, accessed on $21^{\text {st }}$ august $2021 @ 10: 39$

6 Eating Well With Sickle Cell, https://www.nemours.org/content/dam/nem ours/wwwv2/filebox/service/medical/sickle cell/sickle-cell-cookbook.pdf , accessed on 25th august 2021@15:32

${ }^{7}$ Salome phelamie, A balanced diet for people with sickle cell disease: 6 food groups and how they help your body, https://www.timesnownews.com/health/arti cle/a-balanced-diet-for-people-with-sicklecell-disease-6-food-groups-and-how-theyhelp-your-body/652199. accessed on 21st august2021@10:20

8 Salome phelame A balanced diet for people with sickle cell disease: 6 food groups and how they help your body, https://www.timesnownews.com/health/arti cle/a-balanced-diet-for-people-with-sicklecell-disease-6-food-groups-and-how-theyhelp-your-body/652199. accessed on $21 \mathrm{st}$ august 2021@10:20

9 Salome phelamie, A balanced diet for people with sickle cell disease: 6 food groups and how they help your body, https://www.timesnownews.com/health/arti cle/a-balanced-diet-for-people-with-sicklecell-disease-6-food-groups-and-how-theyhelp-your-body/652199. accessed on $21 \mathrm{st}$ august $2021 @ 10: 23$

${ }^{10}$ Salome phelamie, A balanced diet for people with sickle cell disease: 6 food groups and how they help your body, https://www.timesnownews.com/health/arti cle/a-balanced-diet-for-people-with-sicklecell-disease-6-food-groups-and-how-theyhelp-your-body/652199. accessed on $21 \mathrm{st}$ august $2021 @ 10: 24$

11 Boston Medical Center Department of Food and Nutrition Services, https://www.bmc.org/sites/default/files/Abo ut_Us/Features/Sickle_Cell_Disease_Treat ment_at_BMC/field_Attachments/SickleCe 1lDisease-EatingHealthy.pdf, accessed on $21^{\text {st }}$ august $2021 @ 10: 42$

12 Boston Medical Center Department of Food and Nutrition Services, https://www.bmc.org/sites/default/files/Abo ut_Us/Features/Sickle_Cell_Disease_Treat ment_at_BMC/field_Attachments/SickleCe 
11Disease-EatingHealthy.pdf, accessed on $21^{\text {st }}$ august $2021 @ 10: 44$

${ }^{13}$ Umeakunne K, Hibbert JM, Nutrition in sickle cell disease: recent insights, https://www.dovepress.com/nutrition-insickle-cell-disease-recent-insights-peerreviewed-fulltext-article-NDS\#CIT0022, accessed on 21 ${ }^{\text {st }}$ august $2021 @ 11: 07$ 14

${ }^{15} \mathrm{https}: / /$ www.medicalnewstoday.com/articl es/323259, accessed on 21 ${ }^{\text {st }}$ august $2021 @$ $11: 14$

${ }^{16} \mathrm{https}: / / \mathrm{www} . \mathrm{medicalnewstoday.com/articl}$ es/323259, accessed on 21 ${ }^{\text {st }}$ august2021@ $11: 14$

${ }^{17} \mathrm{https}: / /$ www.medicalnewstoday.com/articl es/323259, accessed on 21 ${ }^{\text {st }}$ august $2021 @$ $11: 14$

${ }^{18} \mathrm{https}: / / \mathrm{www} . \mathrm{medicalnewstoday.com/articl}$ es/323259, accessed on 21 ${ }^{\text {st }}$ august2021@ $11: 14$

${ }^{19} \mathrm{https}: / / \mathrm{www} . \mathrm{medicalnewstoday.com/articl}$ es/323259, accessed on 21 ${ }^{\text {st }}$ august $2021 @$ $11: 14$

${ }^{20} \mathrm{https}: / / \mathrm{www} . \mathrm{medicalnewstoday.com/articl}$ es/323259, accessed on 21 ${ }^{\text {st }}$ august $2021 @$ $11: 14$

${ }^{21}$ Umeakunne K, Hibbert JM, Nutrition in sickle cell disease: recent insights, https://www.dovepress.com/nutrition-insickle-cell-disease-recent-insights-peerreviewed-fulltext-article-NDS\#CIT0022, accessed on 21 ${ }^{\text {st }}$ august $2021 @ 11: 17$
${ }^{22}$ Umeakunne K, Hibbert JM, Nutrition in sickle cell disease: recent insights, https://www.dovepress.com/nutrition-insickle-cell-disease-recent-insights-peerreviewed-fulltext-article-NDS\#CIT0022, accessed on 21 ${ }^{\text {st }}$ august $2021 @ 11: 20$

${ }^{23} \mathrm{https}$ ://www.fitbase.com/blog/8-bestglutamine-rich-foods-for-overall-wellbeing/ ,accessed on $21^{\text {st }}$ august 2021 @11:23

${ }^{24}$ https://www.fitbase.com/blog/8-bestglutamine-rich-foods-for-overall-wellbeing/ ,accessed on $21^{\text {st }}$ august 2021 (a) 11:23

${ }^{25} \mathrm{https}$ //Www.fitbase.com/blog/8-bestglutamine-rich-foods-for-overall-wellbeing/ accessed on $21^{\text {st }}$ august 2021 @11:23

${ }^{26} \mathrm{https}$ //Www.fitbase.com/blog/8-bestglutamine-rich-foods-for-overall-wellbeing/ accessed on $21^{\text {st }}$ august 2021 @11:23

${ }^{27} \mathrm{https}$ //www.fitbase.com/blog/8-bestglutamine-rich-foods-for-overall-wellbeing/, accessed on $21^{\text {st }}$ august 2021 @11:23

${ }^{28} \mathrm{https}$ //Www.fitbase.com/blog/8-bestglutamine-rich-foods-for-overall-wellbeing/, accessed on $21^{\text {st }}$ august 2021 (a) 11:23

${ }^{29}$ O Agbai , Anti-sickling effect of dietary thiocyanate in prophylactic control of sickle cell anemia , 
https://pubmed.ncbi.nlm.nih.gov/3795284/, accessed on 21 ${ }^{\text {st }}$ august $2021 @ 11: 50$

${ }^{30}$ Olu Israel Oyewole, Sylvia Malomo, Joseph AdebayoComparative studies on antisickling properties of thiocyanate, tellurite and hydroxyurea, https://www.researchgate.net/publication/2 96769062_Comparative_studies_on_antisic kling_properties_of_thiocyanate_tellurite_a nd_hydroxyurea, accessed on $21^{\text {st }}$ august $2021 @ 12: 26$

${ }^{31}$ Freda Dzifa Intiful \& Bernardine Tuah, Diet and nutrition in sickle cell disease, https://www.graphic.com.gh/news/health/di et-and-nutrition-in-sickle-cell-disease.html , accessed on 21st august $2021 @ 12: 33$

${ }^{32}$ Freda Dzifa Intiful \& Bernardine Tuah, Diet and nutrition in sickle cell disease , https://www.graphic.com.gh/news/health/di et-and-nutrition-in-sickle-cell-disease.html , accessed on 21st august 2021@12:33

${ }^{33}$ Freda Dzifa Intiful \& Bernardine Tuah , Diet and nutrition in sickle cell disease, https://www.graphic.com.gh/news/health/di et-and-nutrition-in-sickle-cell-disease.html , accessed on 21st august $2021 @ 12: 38$ ${ }^{34}$ Freda Dzifa Intiful \& Bernardine Tuah, Diet and nutrition in sickle cell disease , https://www.graphic.com.gh/news/health/di et-and-nutrition-in-sickle-cell-disease.html , accessed on 21st august $2021 @ 12: 40$

${ }^{35}$ Freda Dzifa Intiful \& Bernardine Tuah, Diet and nutrition in sickle cell disease , https://www.graphic.com.gh/news/health/di et-and-nutrition-in-sickle-cell-disease.html , accessed on 21st august 2021@12:40

${ }^{36} \mathrm{Om}$ B. Jahagirdar, $1,{ }^{*}$ Aditya $\mathrm{M}$. Mittal,1,* Waogwende L. Song-Naba, et al. , Diet and gender influence survival of transgenic Berkley sickle cell mice, https://www.ncbi.nlm.nih.gov/pmc/articles/ PMC6669136/ accessed on $24^{\text {th }}$ august $2021 @ 12: 02$

${ }^{37}$ Ahmed A Daak, Kebreab Ghebremeskel, et al., Effect of omega-3 (n-3) fatty acid supplementation in patients with sickle cell anemia: randomized, double-blind, placebo-controlled trial, https://academic.oup.com/ajen/article/97/1/ $37 / 4577076$, accessed on $24^{\text {th }}$ august 2021 @12:24

${ }^{38}$ Hyacinth I. Hyacinth, Oluwatoyosi A. Adekeye, and Christopher S. Yilgwan, Malnutrition in Sickle Cell Anemia: Implications for Infection, Growth, and Maturation,

https://www.ncbi.nlm.nih.gov/pmc/articles/ PMC3848498/ , accessed on $24^{\text {th }}$ august 2021@12:30

${ }^{39}$ Iheanyi Okpala, et al, Addition of Multimodal Therapy to Standard Management of Steady State Sickle Cell Disease, https://www.hindawi.com/journals/isrn/201 $3 / 236374 /$, accessed on $24^{\text {th }}$ august 2021 (a) $12: 40$ 
${ }^{40}$ Kotue $\mathrm{TC}^{*}$, Djote WNB, Marlyne M, et

al., Antisickling and Antioxidant Properties

of Omega-3 Fatty Acids EPA/DHA, https://juniperpublishers.com/nfsij/pdf/NFS IJ.MS.ID.555752.pdf, accessed on 24th august $2021 @ 12: 50$

${ }^{41}$ Omega-3 Fatty Acids , https://ods.od.nih.gov/factsheets/Omega3Fa ttyAcids-Consumer/ , accessed on 24th august 2021@12:56

${ }^{42}$ David R. Archer, et al., C-Reactive Protein and Interleukin-6 Are Decreased in Transgenic Sickle Cell Mice Fed a High Protein Diet, https://www.ncbi.nlm.nih.gov/pmc/articles/ PMC3755955/\#R41, accessed on $25^{\text {th }}$ august 2021@16:09

${ }^{43}$ Shahida A. Khan, Precipitating factors and targeted therapies in combating the perils of sickle cell disease--- A special nutritional consideration, https://nutritionandmetabolism.biomedcentr al.com/articles/10.1186/s12986-016-0109-7 , accessed on 25th august 2021@16:30 ${ }^{44}$ Shahida A. Khan, Precipitating factors and targeted therapies in combating the perils of sickle cell disease--- A special nutritional consideration, https://nutritionandmetabolism.biomedcentr al.com/articles/10.1186/s12986-016-0109-7 , accessed on 25th august $2021 @ 16: 43$ 45 Gupta, A., \& Raskar, S. (2021). An Ayurvedic Management of Sickle Cell
Anemia in Children: A case study. International Journal of Ayurvedic Medicine, $\quad 12(3)$, 714-717. (https://doi.org/10.47552/ijam.v12i3.2081) 